\title{
Estimation of Unconfined Uniaxial Compressive Strength Using Schmidt Hardness and Ultrasonic Pulse Velocity
}

\author{
Cengiz KURTULUS, Fadime SERTÇELIK, Ibrahim SERTÇELIK
}

\begin{abstract}
Unconfined Compressive Strength (UCS) of the rocks plays a significant role in geotechnical and rock engineering projects. Due to difficulties UCS estimation is done using indirect methods such as Schmidt Rebound Hammer (RN) and Ultrasonic Pulse Velocity (UPV) tests that are quick and inexpensive tests. This study was performed to provide data consisting of correlations between RN versus UPV and UCS for rock materials. RN and UCS and UPV tests were carried out on 66 rock specimens from 6 different rock samples in the laboratory. Linear models were used for the relations between RN and UCS and UPV because $R^{2}$ values of linear model is more suitable than non-linear models. The equations proposed in this study can be used easily for the areas formed of sandstone, limestone, arkoses, and granite to pre-estimate the UCS values of the rocks.
\end{abstract}

Keywords: geotechnical parameters; Schmidt Hardness; Uniaxial Compressive Strength; Ultrasonic Pulse Velocity

\section{INTRODUCTION}

The ultrasonic pulse velocity (UPV) and unconfined compressive strength (UCS) of rocks are very significant for designing geotechnical applications such as tunnel and dam, rock fragmentation in a quarry, rock excavation, drilling and rock blasting. On the other hand, unconfined compressive strength test is exhausting, expensive test because it needs cylindrical core or cubical specimen preparation and testing based on the international standards which are difficult and also not practical in case of weathered rock types $[1,2]$. For these troubles, UCS has been determined from the use of indirect methods [3]. The Schmidt hammer test was considered for rock strength determination [4].The test was standardized by [5] and [6] for collecting valuable data. The Schmidt Hammer is a portable device designed to measure the surface hardness of the rocks and concrete. For its operation, a hammer is released by a spring by pushing a switch, its plunger strikes against the rock surface indirectly and then RN is read directly from its scale changing from 10 to 100 . RN of mass indicates the rebound hardness or Schmidt hardness. The Schmidt hammer is portable, rapid and has the nondestructive procedure of application. For this reason, it has been used worldwide for a quick rock strength estimation. The researchers [7] indicated that RN value could be a good indicator for determining the rock discontinuity and compressive strength. [8] have used the Schmidt hammer to determine the surface hardness of natural rocks. [9] checked the point load index, $\mathrm{RN}$ values and $\mathrm{E}$ of gabbros and basalts, and obtained empirical relationships for gabbros and basalts. [10] estimated UCS using the slake durability and $\mathrm{RN}$ tests based on analysis of structural and physical material properties affecting both strength and durability. The author [11] has made the correlations between UCS and RN on published 48 different rocks and indicated that the range of the test results is within acceptable limits for most engineering purposes.The authors [12] have given ampirical relations between RN and UCS and Young's modulus for andesites, basalts and tuffs. The researchers [13] determined an empirical equation between RN and UCS for igneous, metamorphose and sedimentary rock specimens. The authors [14] conducted Schmidt hardness test to estimate the mechanical properties of rocks, particularly the unconfined compressive strength, under specific geological circumstances and introduced an equation to estimate (UCS) of roof rock from the RN values. The authors [15] proposed a relationships between Schmidt rebound hammer test and concrete destructive compression test. They presented a study on the calibration of Schmidt rebound Hammer with various aged concretes. The researchers [16] determined a linear relationship for $\mathrm{RN}$ versus specific gravity and tensile strength versus point load index. The authors [17] investigated the relationships between UPV and RN versus UCS of rocks. The authors [18] determined a relationship between UPV, RN and the tensile strength of limestone, sandstone, marl, and tuff.

\section{EXPERIMENTAL PROCEDURES}

A total of 66 intact rock blocks were taken from 6 several rocks at the study area of which 8 samples from Sopalı arkoses, 14 samples from Derince sandstone, 12 samples from each of Körfez sandstone and Akveren limestone, 10 samples from each of Kizderbent volcanic and Hereke limestone (Fig. 1), (Tab. 1). Each block sample was examined for providing testing specimens free from cracks, fracture, and alteration. NX size cylindrical specimens with the diameter of $54 \mathrm{~mm}$ and the length of $110 \mathrm{~mm}$ were prepared using core drill and sawing machines in the laboratory in accordance with the recommendations of [19]. L-type Schmidt hammer with the impact energy $0.735 \mathrm{Nm}$ was performed on rock core specimens to determine the $\mathrm{RN}$ in accordance with the standards given by many authors, ASTM and ISRM $[5,19$, 6]. During the test, the sample was held by cradle in position. 20 Schmidt hammer readings were performed at several points on the each specimen surface. Rebound number value was found from $50 \%$ of the highest $\mathrm{RN}$ values. The unconfined compressive strength of the core specimens was figured out by placing each specimen under increasing loading of a hydraulic testing machine considering the related standard [20]. The ultrasonic pulse velocity measurements of compressional waves were performed with Pundit Plus and DT Quist-120t ultrasonic tester with the $54 \mathrm{kHz}$ transducers. 


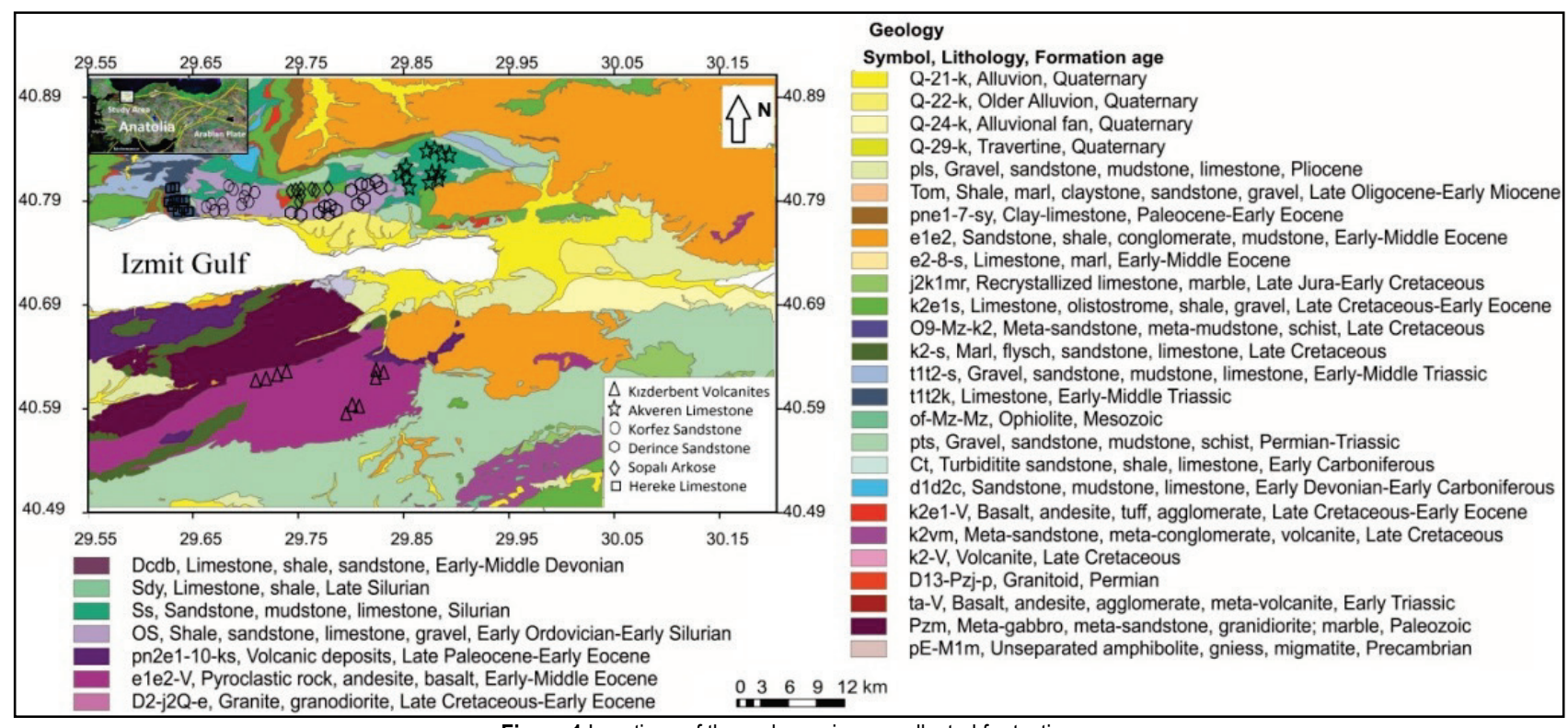

Figure 1 Locations of the rock specimens collected for testing
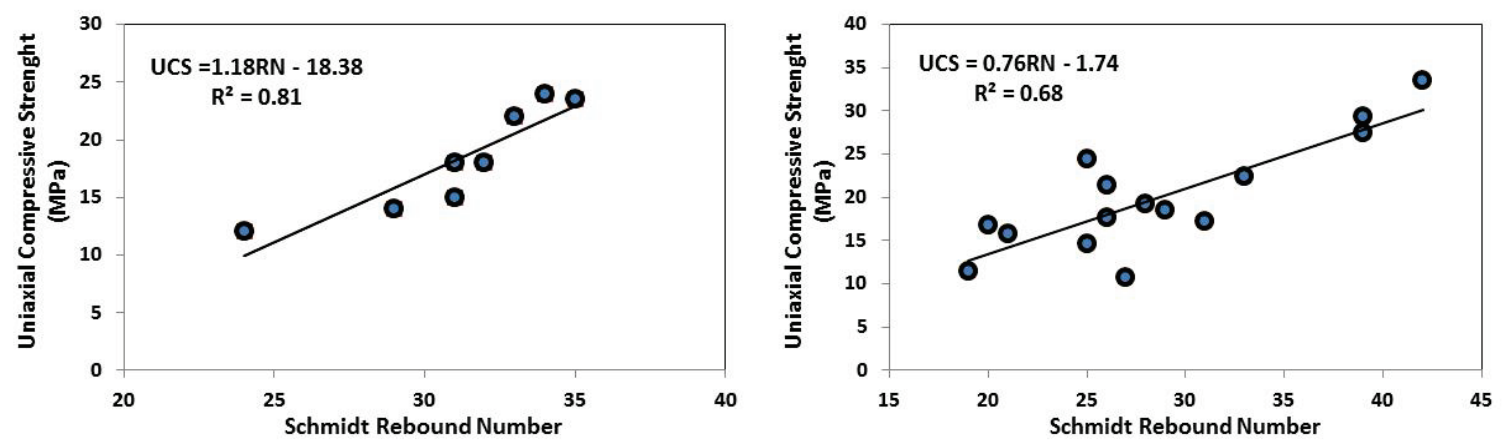

(a) Sopalı Arkoses

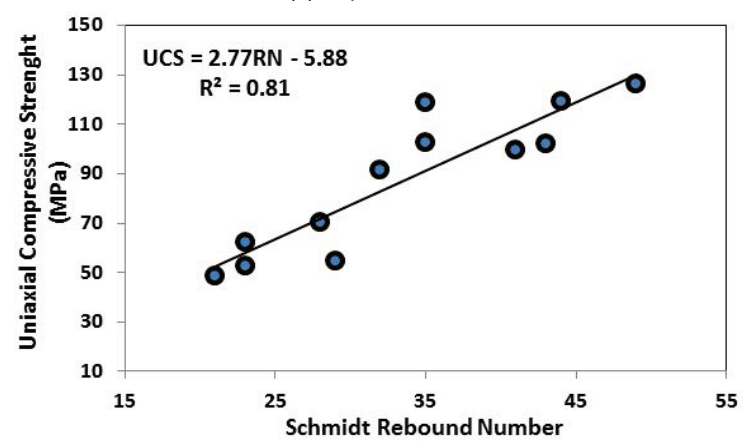

(b) Derince sandstone

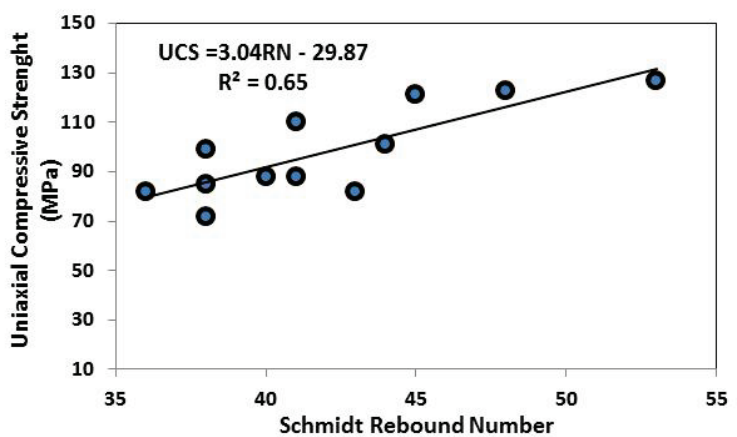

(e) Akveren limestone

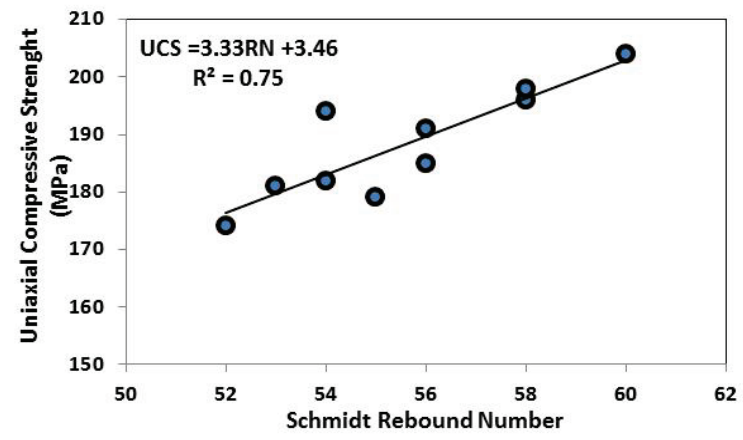

(f) KIzderbent volcanic

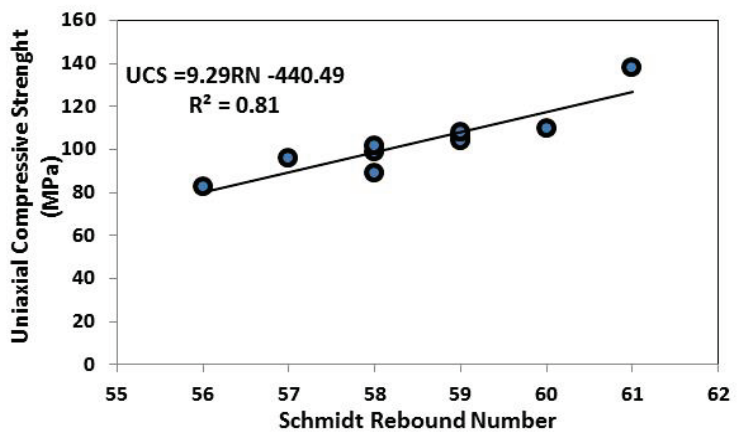

(g) Hereke limestone

Figure 2 Relation between UCS and RN for Sopalı arkoses, Derince sandstone, Körfez sandstone, Akveren limestone Kızderbent volcanic and Hereke Limestone 
Table 1 Rock types and age of the specimens

\begin{tabular}{|c|c|c|}
\hline $\begin{array}{c}\text { Number of } \\
\text { specimens }\end{array}$ & Rock type & Age \\
\hline 8 & Sopalı arkoses & Lower Ordovician \\
\hline 14 & Derince sandstone & Lower Ordovician \\
\hline 12 & Körfez sandstone & Lower Ordovician \\
\hline 12 & Akveren limestone & Upper Cretaceous-Lower Eocene \\
\hline 10 & Kizderbent volcanic & Lower-Middle Eocene \\
\hline 10 & Hereke limestone & Early-Middle Triassic \\
\hline
\end{tabular}

\subsection{Data Analysis}

The results of 66 laboratory tests (RN,UPV, and UCS are tabulated in Tab. 2. The data were evaluated to figure out the relation between RN and UCS. Fig. 2 demonstrates the relations between RN and UCS of Sopalı arkoses, Derince sandstone, Kızderbent sandstone, Akveren limestone, Kizderbent volcanic and Hereke limestone. Compressive strength increases with the increasing rebound number for all of the rock types. A linear relationship was determined between UCS and RN with the reasonably good correlation coefficients $\left(R^{2}=0.65-0.84\right)$

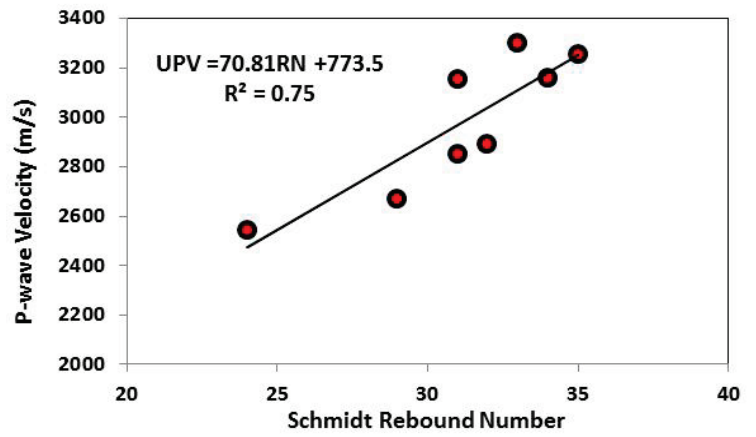

(a) Sopalı Arkoses

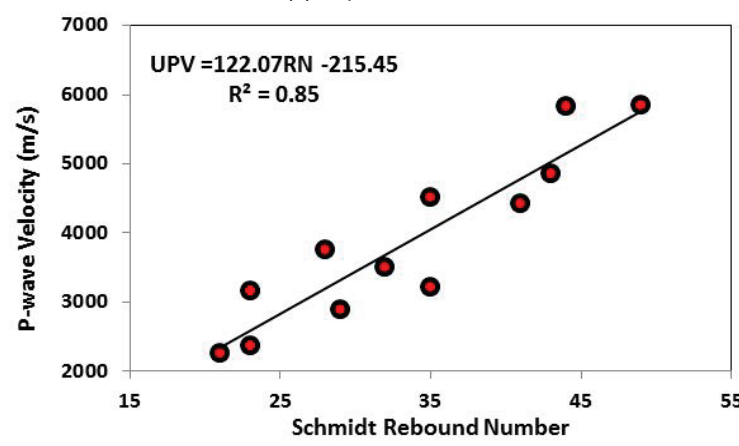

(d) Körfez sandstone

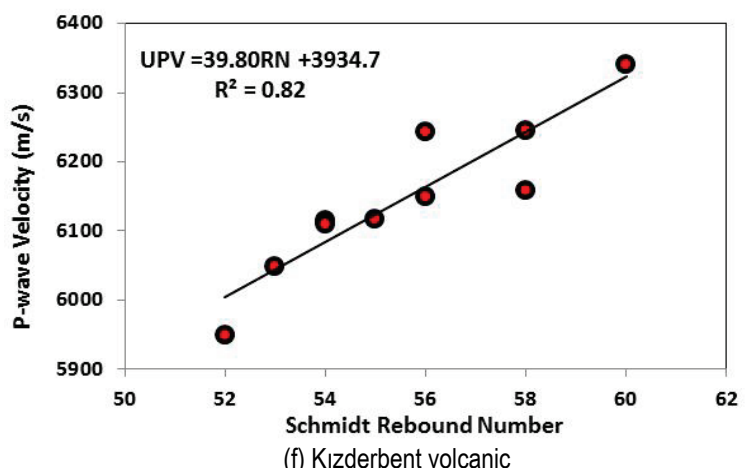

for each rock type (Tab. 2). Fig. 3 indicates the relationships between $\mathrm{RN}$ and UCS for studied rocks. A linear relation with the modarately high correlation coefficient value $\left(R^{2}=0.63\right)$ was determined between $\mathrm{RN}$ and UCS.

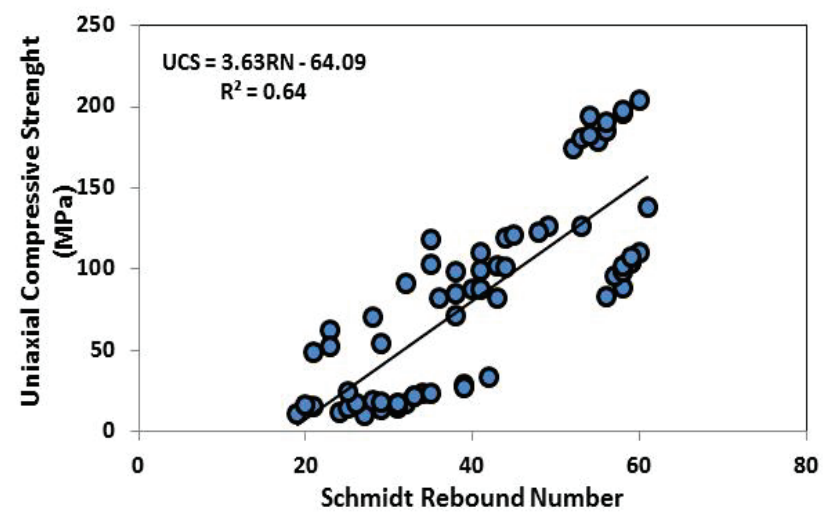

Figure 3 The relationship between RN and UCS for all rock types studied

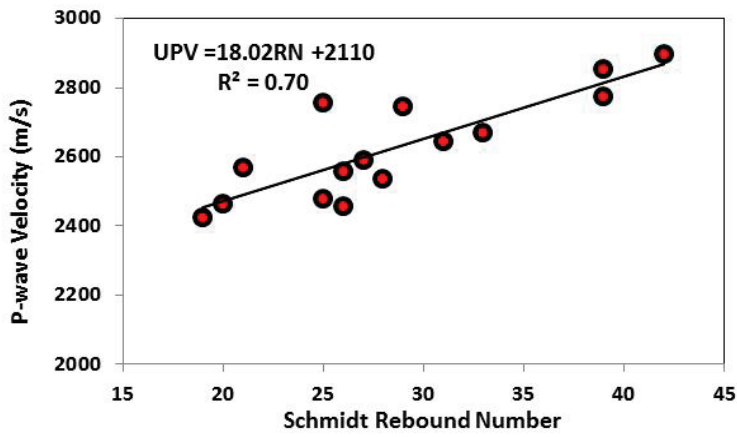

(b) Derince sandstone

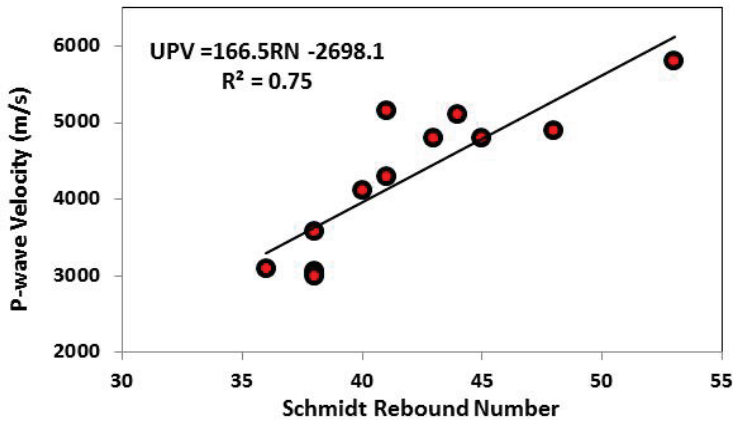

(e) Akveren limestone

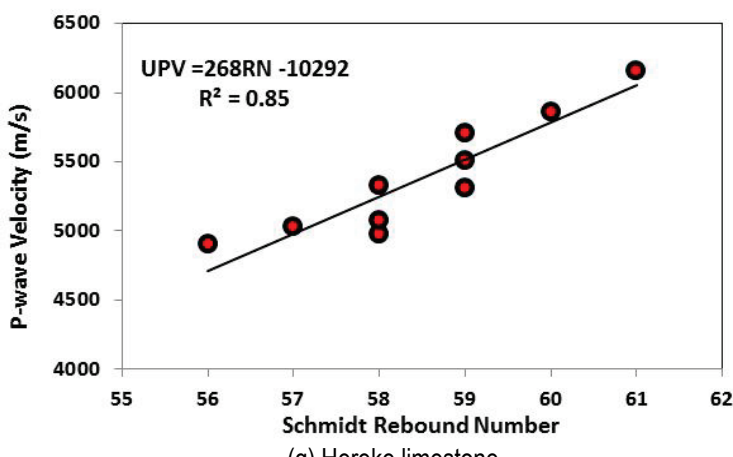

(g) Hereke limestone 


\subsection{Relation Between Ultrasonic Pulse Velocity and Rebound Number}

Relations between RN and UPV of the rock specimens prepared from studied rocks are shown in Fig. 4. As seen from the figures UPV increases as rebound number increases for each of rock type studied. Fig. 5 indicates the general relation between UPV and $\mathrm{RN}$ for all rock types studied.

A linear relationship was determined between UPV and $\mathrm{RN}$ with high correlation coefficients which range between 0.70 and 0.85 (Tab. 2). A linear relation with the high correlation coefficient value $\left(R^{2}=0.83\right)$ was determined between UPV and RN.

\subsection{The Relation between RN, UPV and UCS}

The relation between these three variables was evaluated by MatlabR2010b. Fig. 6 shows these relations for Sopalı arkoses, Derince sandstone, Körfez sandstone, Akveren limestone, Kizderbent volcanics and Hereke

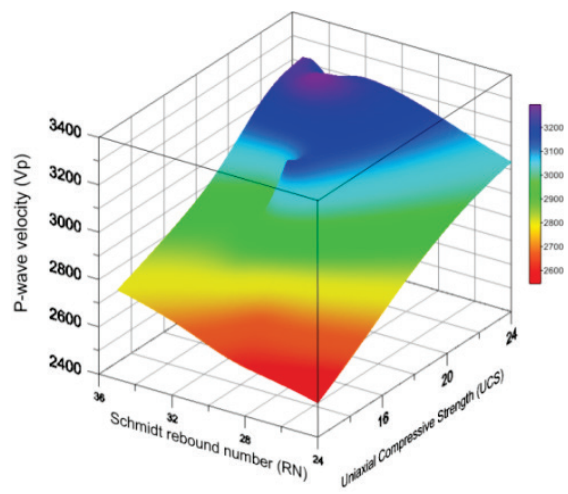

(a) Sopalı arkoses

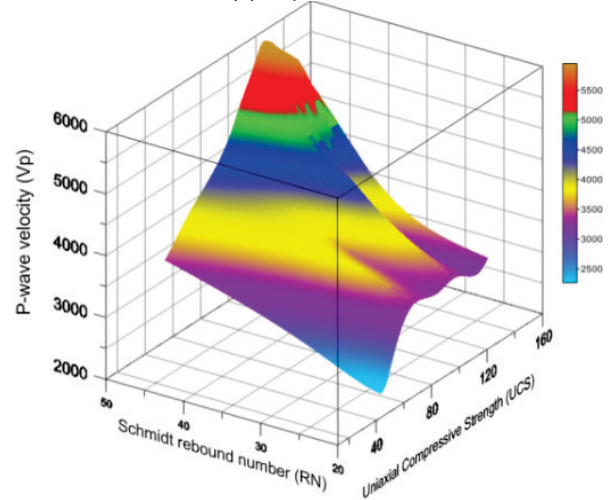

(c) Körfez sandstone

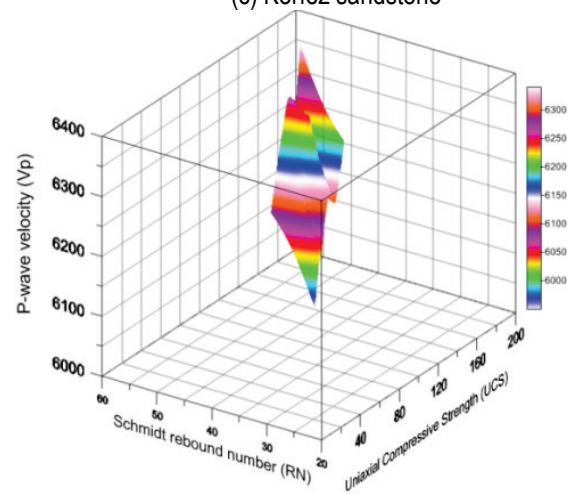

(e) Kızderbent volcanic

Figure 6 Relation between ultrasonic pulse velocity and compressive strength versus rebound number of (a) Sopalı arkoses, (b) Derince sandstone, (c) Körfez sandstone,

(d) Akveren limestone, (e) Kızderbent volcanic and (f) Hereke limestone (f) Hereke limestone

limestone. Fig. 7 domonsrates the relationships between UPV, RN agains to UCS all rocks. As you can see from the figures, linear relationsips were determined among these parameters for all of the rock types.

Tab. 2 summarizes the correlation equations and their $R^{2}$ values. These equations can be considered to find the approximate UCS using their ultrasonic velocity and RN.

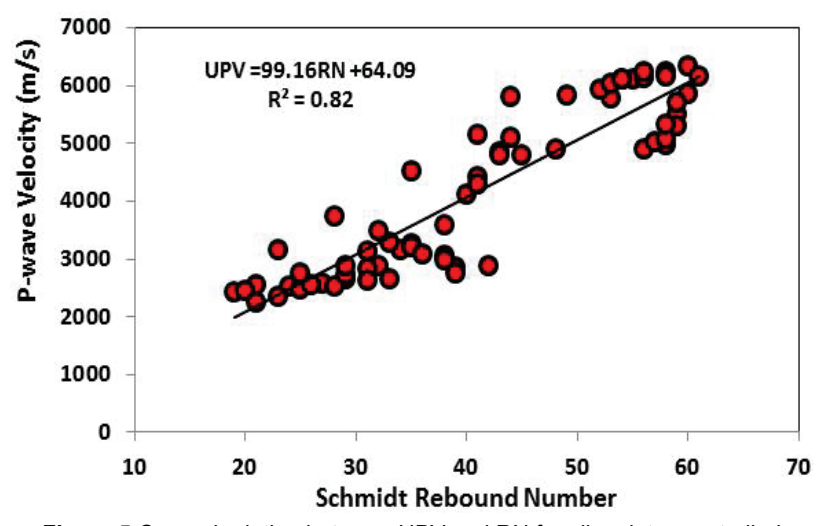

Figure 5 General relation between UPV and RN for all rock types studied

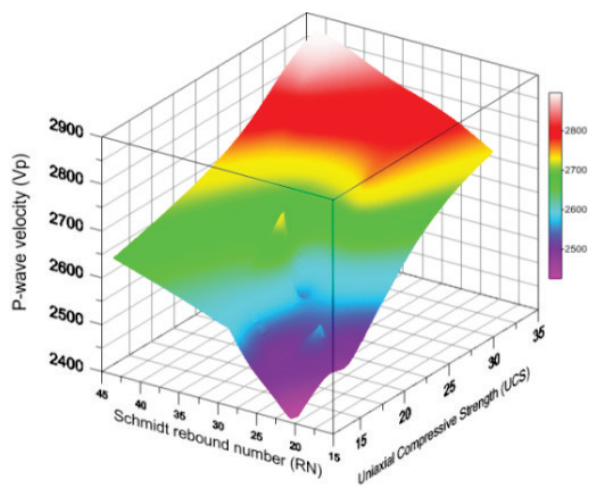

(b) Derince sandstone

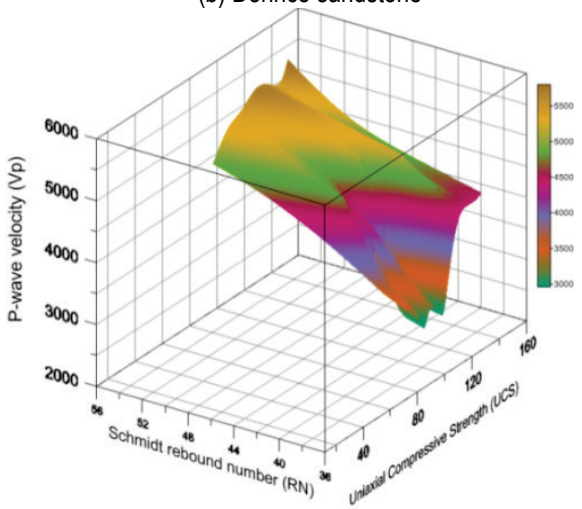

(d) Akveren limestone

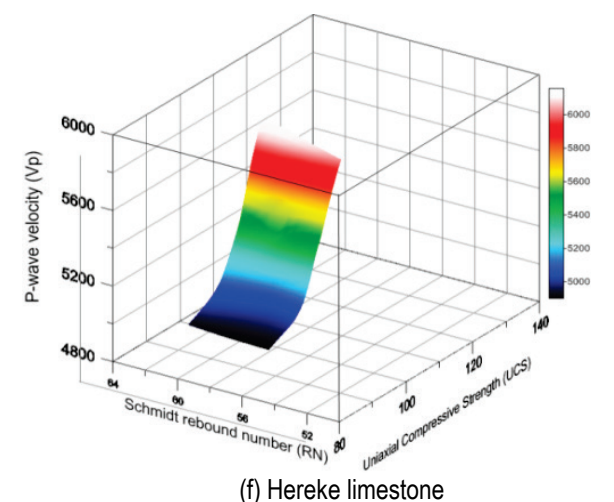
Technical Gazette 25, 5(2018), 1569-1574 


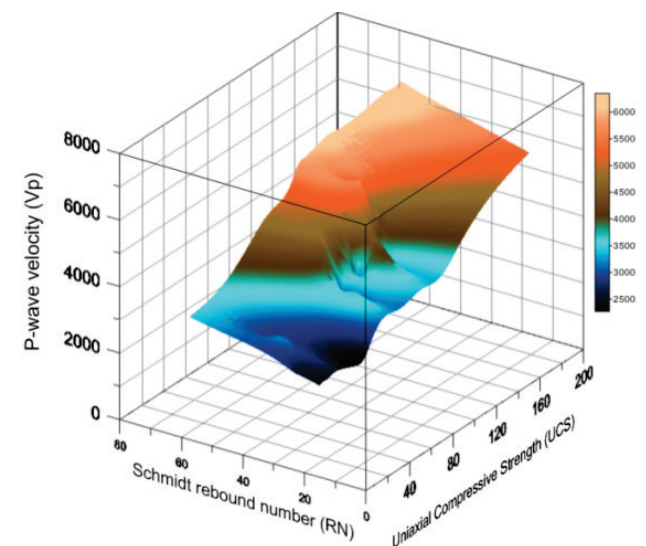

Figure 7 General relations between, UPV, RN against to UCS of all rock types

\section{RESULT AND DISCUSSION}

Regression analysis was applied to correlate rebound number with compressive strength and ultrasonic pulse velocity for each of rock type. Sopalı arkoses, Derince sandstone, Körfez sandstone, Akveren limestone, Kizderbent volcanic and Hereke limestone are illustrated in Figs. 2-6, respectively. Tab. 2 represents the relation equations between RN and UCS, RN and UPV and UPV, $\mathrm{RN}$ and UCS for all the rock types. Linear relationships were found between the RN and UCS of the rocks studied with the correlation coefficients ranging between $R^{2}=0.64$ - 0.81. The general correlation equation between these parameters for all studied rocks is also linear but its correlation coefficient is slightly lesser than that of the individual rock (Tab. 2). RN values increase as the UCS values increase. These equations are similar to those given by $[9,12,14]$. The relationship between RN and UPV was also determined linear with the correlation coefficient ranging $R^{2}=0.70-0.85$ for the rocks studied. The general correlation equation between RN and UPV for all studied rocks is also linear with the correlation coefficient of $R^{2}=$ 0.83 , Tab. 2 . The $\mathrm{RN}$ values increase with increasing UPV values. The relations between RN and UPV values are not found in the literature widely so far. Therefore, this may be the first study in which the relations between RN and UPV were determined for different rock types. The correlation equations among the UPV, RN and UCS are exponential for arkoses and Hereke limestone and linear for the other rocks, Tab. 2. The linear equations show similarities with the equations determined by [17].

Table 2 Suggested models for correlations between RN and UCS, RN and UPV and UPV and RN agains to UCS of rock types

\begin{tabular}{|c|c|c|c|c|c|}
\hline Rock type & $\mathrm{RN}$ & UCS & UPV & Empirical equation & $R^{2}$ \\
\hline \multirow{3}{*}{ Sopalı Arkoses } & \multirow{3}{*}{$24-35$} & \multirow{3}{*}{$12-24$} & \multirow{3}{*}{$2544-3255$} & $\mathrm{UCS}=1.18(\mathrm{RN})-18.38$ & 0.81 \\
\hline & & & & $\mathrm{UPV}=70.81(\mathrm{RN})+773.5$ & 0.75 \\
\hline & & & & $\mathrm{UCS}=6 \mathrm{e}^{-006} \times(\mathrm{UPV})^{1.314} \times(\mathrm{RN})^{1.297}$ & 0.91 \\
\hline \multirow{3}{*}{ Derince sandstone } & \multirow{3}{*}{$20-42$} & \multirow{3}{*}{$10-33$} & \multirow{3}{*}{ 2464-2896 } & $\mathrm{UCS}=0.76(\mathrm{RN})-1.74$ & 0.68 \\
\hline & & & & $\mathrm{UPV}=18.02(\mathrm{RN})+2110$ & 0.70 \\
\hline & & & & $\mathrm{UCS}=6.58 \mathrm{e}^{-008} \times(\mathrm{UPV})^{2.17} \times(\mathrm{RN})^{1.72}$ & 0.76 \\
\hline \multirow{3}{*}{ Körfez sandstone } & \multirow{3}{*}{$21-49$} & \multirow{3}{*}{$52-120$} & \multirow{3}{*}{$2265-5845$} & $\mathrm{UCS}=2.77(\mathrm{RN})-5.88$ & 0.81 \\
\hline & & & & $\mathrm{UPV}=122.07(\mathrm{RN})-215.45$ & 0.85 \\
\hline & & & & $\mathrm{UCS}=2.88 \times(\mathrm{UPV})^{-0.089} \times(\mathrm{RN})^{1.109}$ & 0.81 \\
\hline \multirow{3}{*}{ Akveren limestone } & \multirow{3}{*}{$36-53$} & \multirow{3}{*}{$72-121$} & \multirow{3}{*}{$3054-5148$} & $\mathrm{UCS}=3.04(\mathrm{RN})-29.87$ & 0.65 \\
\hline & & & & $\mathrm{UPV}=166.5(\mathrm{RN})-2698.1$ & 0.75 \\
\hline & & & & $\mathrm{UCS}=0.98 \times(\mathrm{UPV})^{-0.08} \times(\mathrm{RN})^{1.415}$ & 0.72 \\
\hline \multirow{3}{*}{ Kizderbent volcanic } & \multirow{3}{*}{$52-60$} & \multirow{3}{*}{$174-204$} & \multirow{3}{*}{$5950-6340$} & $\mathrm{UCS}=3.33(\mathrm{RN})+3.46$ & 0.75 \\
\hline & & & & $\mathrm{UPV}=39.801(\mathrm{RN})+3934.7$ & 0.82 \\
\hline & & & & $\mathrm{UCS}=0.013 \times(\mathrm{UPV})^{0.77} \times \mathrm{RN}^{0.69}$ & 0.76 \\
\hline \multirow{3}{*}{ Hereke limestone } & \multirow{3}{*}{$56-61$} & \multirow{3}{*}{$83-138$} & \multirow{3}{*}{$4900-6158$} & $\mathrm{UCS}=9.29(\mathrm{RN})-440.49$ & 0.81 \\
\hline & & & & $\mathrm{UPV}=268(\mathrm{RN})-10292$ & 0.85 \\
\hline & & & & $\mathrm{UCS}=9.48 \mathrm{e}^{-006} \times(\mathrm{UPV})^{0.98} \times(\mathrm{RN})^{1.90}$ & 0.87 \\
\hline \multirow{3}{*}{ All rocks } & \multirow{3}{*}{$20-61$} & \multirow{3}{*}{$12-204$} & \multirow{3}{*}{$2265-6340$} & $\mathrm{UCS}=3.63(\mathrm{RN})-64.09$ & 0.64 \\
\hline & & & & $\mathrm{UPV}=99.166(\mathrm{RN})+64.09$ & 0.82 \\
\hline & & & & $\mathrm{UCS}=8.52 . \mathrm{e}^{007} \times(\mathrm{UPV})^{2.3} \times(\mathrm{RN})^{-0.36}$ & 0.83 \\
\hline
\end{tabular}

The test results showed that the Hereke limestone has the maximum average RN and UPV values whereas, the Kizderbent volcanic has the maximum average UCS and UPV values, and the Sopalı arkoses has the minimum average RN and UCS values. Derince sandstone has the minimum average UPV values.

\section{CONCLUSION}

Review of the literature showed that a great deal of studies have been conducted to estimate the UCS of rocks which plays an important role in rock engineering and construction projects in a fast, easy and precise way since the determination of UCS is expensive, tiresome and time consuming. Some of the authors proposed correlation equations between UPV and UCS [11], and some of the others proposed empirical equations between $\mathrm{RN}$ and UCS.
In this research work, RN, UPV, and UCS were performed on 6 different types of rocks located in the North-Western part of Turkey to determine relations between RN and UCS and also RN and UPV. Linear models were used for the relations between RN and UCS and UPV since correlation cofficents $\left(R^{2}\right)$ of linear model are greater than correlation cofficents of nonlinear models. Estimation of UCS for studied rocks using relations determined between RN and UCS and RN and UPV values of all the studied rocks (Figs. 2 and 4) was generally more reliable than using general relation between, UPV, RN versus UCS of all the studied rocks (Figs. 3 and 5). It can be seen that the relationships determined in this study are in acceptable ranges when they are compared with the other relations given by different authors in the literature and can be used as a quick reference to estimate the preliminary value for UCS. 


\section{Acknowledgments}

This research was supported by Kocaeli University of the Scientific Research Project Funding under the project number: 2015/039.

\section{REFERENCES}

[1] Gokceoglu, C. \& Zorlu, K. A. (2004). Fuzzy model to predict the unconfined compressive strength and modulus of elasticity of aproblematic rock. Eng Appl Artif Intell., 17, 6172. https://doi.org/10.1016/j.engappai.2003.11.006

[2] Ceryan, N., Okkan, U., \& Kesimal, A. (2012). Prediction of unconfined compressive strength of carbonate rocksusing artificial neural networks. Environ Earth Sci. https://doi.org/ 10.1007/s12665-012-1783

[3] Schmidt, E. (1951). A non-destructive concrete tester Concrete, 59(8), 34-5

[4] Aydin, A . \& Basu, A. (2005). The Schmidt hammer in rock material characterization. EngGeol., 81, 1-14. https://doi.org/10.1016/j.enggeo.2005.06.006

[5] ISRM. (1978). Suggested methods for determining hardness and abrasiveness of rocks. Int. J. Rock Mech. Min. Sci. Geomech. Abstr., 15, 89-97. https://doi.org/10.1016/0148-9062(78)90002-5

[6] ASTM 2001 D 5873-00. Standard test method for determination of rock hardness by rebound hammer method. 04.09.

[7] Young, R. P. \& Fowell, R. J. (1978). Assessing rock discontinuities. Tunnels and Tunneling, June, 45-48.

[8] Willams, R. \& Robinson, D. (1983). The effect of surface texture on the determination of the surface hardness of rock using Schmidt Hammer. Earth Surface Processes and Landforms, 8, 289-292. https://doi.org/10.1002/esp.3290080311

[9] Aggistalis, G., Alivizatos, A., Stamoulis, D., \& Stournaras, G. (1996). Correlating uniaxial compressive strength with Schmidt hammer rebound number, point load index, Young's modulus, and mineralogy of gabbros and basalts (Northern Greece). Bull Eng Geol, 54, 3-11. https://doi.org/10.1007/BF02600693

[10] Engin, C., Koncagul, E., \& Santi, P. M. (1999). Predicting the unconfined compressive strength of the Breathitt shale using slake durability, Shore hardness and rock structural properties. International Journal of Rock Mechanics and Mining Sciences, 36, 139-153. https://doi.org/10.1016/S0148-9062(98)00174-0

[11] Kahraman, S. (2001). Evaluation of simple methods for assessing the uniaxial compressive strength of rock. Int. J. Rock Mech. Min. Sci. 38, 981-994. https://doi.org/10.1016/S1365-1609(01)00039-9

[12] Dinçer, I., Acar, A., Çobanoğlu, I., \& Uras, Y. (2004). Correlation Between Schmidt Hardness, Uniaxial Compressive Strength and Young's Modulus for Andesites, Basalts and Tuffs. Bull Eng Geol Env. 63, 141-148. https://doi.org/10.1007/s10064-004-0230-0

[13] Yasar, E. \& Erdogan, Y. (2004). Estimation of rock physicomechanical properties using hardness methods. Eng. Geol. 71, 281-288. https://doi.org/10.1016/S0013-7952(03)00141-8

[14] Torabi, S. R., Ataei, M., Javanshir, M. (2010). Application of Schmidt rebound number for estimating rock strength under specific geological conditions. Journal of Mining \& Environment, 1-2, 1-8.

[15] Aydin, F. \& Saribiyik M. (2010). Correlation between Schmidt Hammer and destructive compressions testing for concretes in existing buildings. Scientific Research and Essays, 5(13), 1644-1648.
[16] Gurocak, Z., Solanki, P., Alemdag, S., \& Zaman, M. (2012). New considerations for empirical estimation of tensile strength of rocks. Engineering Geology, 145-146, 1-8. https://doi.org/10.1016/j.enggeo.2012.06.005

[17] Aliabdo, A. \& Elmoaty A. E. M. A. (2012). Reliability of using nondestructive tests to estimate compressive strength of building stones and bricks. Alexandria Engineering Journal / Alexandria University, Egypt. https://doi.org/10.1016/j.aej.2012.05.004

[18] Hosseini, M. \& Shirin, D. (2015). An estımate of the tensile strength based on p-wave velocity and schmidt hardness rebound number. International Journal of Geography and Geology, 4(2), 24-36. https://doi.org/10.18488/journal.10/2015.4.2/10.2.24.36

[19] ISRM 2007. The complete ISRM suggested methods for rock characterization, testing and monitoring: 1974-2006. In: Ulusay, Hudson (Eds.), Suggested methods prepared by the commission on testing methods. International Society for Rock Mechanics. ISRM Turkish National Group, Ankara, Turkey: 628

[20] ASTM 2010, D7012-10. Standard test method for compressive strength and elastic moduli of intact rock core specimens under varying states of stress and temperatures.

\section{Contact information}

Prof. Dr. Cengiz KURTULUS

Kocaeli University, Umuttepe Campus, Engineering Faculty,

Department of Geophysisc, 41380 Kocaeli/Turkey

E-mail: cengizk@kocaeli.edu.tr

Assoc. Prof. Dr. Fadime SERTCELIK (Corresponding Author) President of Seismology Department,

Kocaeli University, Umuttepe Campus, Engineering Faculty,

Department of Geophysisc, 41380 Kocaeli/Turkey

E-mail: fasert@kocaeli.edu.tr

Assoc. Prof. Dr. Ibrahim SERTCELIK

Kocaeli University, Umuttepe Campus, Engineering Faculty, Department of Geophysisc, 41380 Kocaeli/Turkey

E-mail: isert@kocaeli.edu.tr 